\title{
TEACHERS' WRITTEN FEEDBACK: HOW TO MAKE IT WORK MORE EFFECTIVELY IN A LANGUAGE CLASSROOM?
}

\author{
Phung Thi Kim Dung* \\ VNU University of Languages and International Studies \\ Pham Van Dong, Cau Giay, Hanoi, Vietnam
}

Received 26 December 2019

Revised 21 April 2020; Accepted 30 May 2020

\begin{abstract}
Teachers' response to student writing is a vital, though neglected, aspect of second language composition research. This present study adds to previous research through the development and implementation of an original study which investigates the current feedback-giving practice of the teachers and their students' opinions on feedback as well as their recommendations for improving it. The subjects involved in the study were 200 second-year students and 20 teachers at the University of Languages and International Studies (ULIS) under Vietnam National University, Hanoi (VNU) who are currently teaching or have taught writing before. These teachers and students were invited to join the survey, to answer the questionnaires, to participate in the interview, and to provide the source for observation. The research reveals that there exist a lot of problems concerning teachers' responding methods, their feedback focus, their frequent types and forms of feedback as well as what they have actually done to help their students process feedback successfully. Meanwhile, the students report their opinions and preferences for more effective teachers' feedback, which clearly reveals the mismatch between what the teachers often give and what the students would like to get. On this basis, the study recommends several important directions for teachers to utilize in improving their feedback, helping students process feedback more effectively and thus creating a condition in which learners learn to write more easily and successfully.
\end{abstract}

Keywords: feedback, process-based vs. product-based approach, content, form, revision

\section{Rationale}

As the process-oriented pedagogy has permeated the writing instructions over the past two decades, teachers have encouraged or required their students to write multiple drafts and explored various ways to provide feedback in order to help students revise their writings. Techniques used to provide feedback to students have included peer reviews, teacher-student conferences, and audiotaped commentary. Still, for many teachers,

Tel.: 84-943032992

Email: kimdungspta@gmail.com handwritten commentary on students' drafts is the primary method of response.

Despite the importance of teachers' written feedback, research in this area has been surprisingly scarce. In addition, many studies which have been done so far lack consensus over how teachers should respond to students' writing. Some others have been limited in terms of scale and sample size. Still, some others have examined only a single aspect of teachers' feedback, thus yielding insufficient information concerning the matter area.

In the meantime, in Vietnam, there have been few or no studies into feedback in general and teachers' feedback in particular. At the Faculty of English Language Teacher Education (FELTE), ULIS-VNU, there have 
been no attempts to investigate the issue. It would appear that the teachers' current responding practice is lacking in specific theoretical foundations.

The above reasons have urged the author, who is also the teacher of composition at the Faculty, to explore this important, but by no means neglected issue in an attempt to address the gap in the literature and to offer the teachers in her Faculty, in the second English division in particular, ways on how they should respond to students' writing.

\section{Purposes of the study}

This research is designed to break new ground in examining teachers' written feedback on the second-year students' writings at FELTE, ULIS-VNU. It wishes to achieve the three primary aims:

(i) to investigate the teachers' feedbackgiving practice in the second-year writing classes;

(ii) to investigate the students' reactions towards the feedback they received and their recommendations for improving it;

(iii) to propose some recommendations and suggestions for the teachers to improve their practice.

To achieve the above-mentioned aims, the following research questions were asked:

(i) How do the teachers respond to the students' writing?

(ii) What have the teachers done to help the students process their feedback successfully?

(iii) What problems do the teachers encounter in responding to the students' writing?

(iv) What are the students' opinions on the feedback they received?

(v) What do the students want their teachers to do to help them revise more effectively?

\section{Theoretical background}

\subsection{An overview of the process approach}

Central to this approach is the view that writing is a process which contains a number of stages or activities writers have to go through in order to produce a good piece of writing. But this process is not a straightforward, planoutline-write process that many believe it to be; rather it is a "complex, recursive, and creative process whereby the writers discover and reformulate their ideas as they attempt to approximate meaning” (Zamel, 1983, p. 165). Guidance through and intervention in the process were seen preferable to control - that is, the early and perhaps premature imposition of organizational patterns or syntactic or lexical constraints. Content, ideas, and the need to communicate would determine form. In essence, "composing means expressing ideas, conveying meaning. Composing means thinking" (Raimes, 1992, p. 261)

This focus on content to the exclusion of form, however, has been the target for attack by the academic community, who argued, "student writing must fall within the range of acceptable writing behaviors dictated by the academic community" (Silva, 1990, p. 17).

Therefore, it seems a comprehensive theory integrating a focus on product into the process approach is the most satisfactory alternative to the previously described, dogmatic theories in the sense that it can guarantee the quality of both form and content as Reid (1993, p. 30) stated, such an approach enables "learners to write their way into more precise, interpretive texts, while at the same time fostering greater attention to forms of the writing, to reflection on what is involved in the creation of a text and to adapting writing style to the audience and context of writing".

\subsection{Stages in the writing process}

Process writing as a classroom activity incorporates the five basic writing stages: prewriting, planning, drafting, revising, and editing - and three other stages externally imposed on students by the teachers, namely, responding, evaluating, and post-writing. Among these stages teacher's responding is proved to be an indispensable part of the process. Therefore, the following section will 
look specifically at teacher feedback as the main component of this stage.

\subsection{Theoretical background to teachers" feedback}

\subsubsection{Definition of feedback}

Feedback is generally defined as "any input from reader to writer that provides information for revision" (Keh, 1989, p. 18). Students need this kind of information from different angles apart from their own in order to develop their writing more comprehensively. Teachers' feedback is thus truly an effective means to instruct the students on how to revise their papers.

\subsubsection{The importance of teachers'feedback}

Feedback, first of all, is considered a pedagogical tool for students' writing improvement. According to Leki (1990), teachers' feedback can even serve as "the final arbiter of whether a writer will continue to write at all" (p. 58). In addition, provision of comments helps individualize writing instructions in that the student writers will be able to get individual attention to have their own needs or problems rightfully addressed (Reid, 1993). Especially, when feedback is combined with instruction in the writing process, the dialogue between student and teachers' is strengthened. Giving and receiving feedback also helps students to develop "reader sensitivity" and their own writing style. Thus feedback is essential to student writing because it creates a context in which students learn to write better and more easily.

\subsubsection{Approaches to giving feedback}

\section{a. Single-draft approach}

Under this approach teachers' responding to students' writing were fairly straightforward. Students write a paper; teachers' return it with a grade and errors marked in red, and perhaps with a few notes of students' performance; and then they switch to a new lesson, students would write a new paper and repeat the process. This traditional practice of one-shot commenting on students' writing proves to be ineffective to students' revision. Therefore, a new approach - the multiple-draft approach to feedback giving seems to be a better alternative.

\section{b. Multiple-draft approach}

This approach requires teachers as part of their instructional role to respond to students' writing as a process, to lead students through several revision cycles before asking them to submit the final piece for evaluation. One advantage of this method is that it gives writers more chance to develop and present their ideas effectively. Another is that it helps avoid turning each paper into a miniature test on which teachers simultaneously comment and evaluate. It thus shows students that writing is the process of improving through revising based on teachers' feedback, rather than a single act of producing one and also the final draft for teachers' evaluation.

\subsubsection{Focus of teachers'feedback}

As teachers are engaged in the process of responding, they are faced with a very fundamental question of what the focus of their feedback should be. Traditionally, teachers and researchers focused mainly on form and the final product. In recent years, there has been emphasis placed on the writing process. Many "process" teachers have focused their comments on an essay's overall shape and intention to help writers present their ideas effectively. Still, some others maintain a strong interest in correctness in spite of this recent focus (Fathman \& Whaley, 1990). Researchers in the field suggested that teachers should pay attention to both content and form of students' writing because any either of them can negatively affect the quality of the written product. Another question to follow is whether these two feedback types should be provided simultaneously or separately. The answer differed among researchers, which suggested that more studies are needed in order to seek more insights into the problem. 


\subsubsection{Types of teachers' feedback}

\section{a. Marginal feedback versus end feedback}

Marginal feedback is a kind of feedback that is written in the margin or between sentence lines of students' paper. It refers to the teacher's immediate intervention in discrete parts of the students' draft. By contrast, summary feedback at the end of the paper is normally an overview of more consideration in an essay.

\section{b. Negative feedback versus positive feedback}

Research into positive and negative comments suggested that students appear to enjoy and appreciate praises; however, they do expect to receive constructive criticism and are not necessarily offended by this. Therefore, teachers should strive for a balance, providing some praise for students' efforts, but not forgetting their crucial instructional role of helping students to revise and improve on what they have done badly.

\section{c. Text-specific feedback versus general}

\section{feedback}

Text-specific feedback is a kind of comment that directly relates to the text at hand whereas general feedback can be attached to any paper. Teachers' feedback is more helpful if it is text-specific (Sommers, 1982; Zamel, 1985; Hillocks, 1986; Reid, 1993; Seow, 2002). However, Ferris (1997) urged that there is a role in teachers' commentary for general responses. A general response of encouragement is no doubt better than none. Her view has been well supported by Fathman and Whalley's perspective: "general comments that do not refer to specifics within the text can be effective ... giving encouragements helped improve the students' rewrites." (1990, p. 186)

\subsubsection{Forms of teachers' written feedback}

According to Ferris (1997), teachers' feedback generally operates within these four basic syntactic forms: question, statement, imperative, and exclamation, which present different pragmatic aims such as giving or asking for further information, making requests for revision, giving positive feedback about what the student has done well. Since each form has its own problems, teachers are recommended to be careful in constructing their own feedback forms, in explaining those feedback forms together with their pragmatic intents to students, and most importantly, in helping students process the comments and revise their drafts effectively.

\subsubsection{Issues in teachers' written feedback}

\section{a. Appropriating students' texts}

This is a phenomenon understood as 'teachers' comments (can) take students' attention away from their own purposes in writing a particular text and focus that attention on the teachers' purpose in commenting" (Sommers, 1982, p. 149); or to put it simply, it is the situation where teachers try to rewrite students' text. Brannon and Knoblauch (1982) thought that it is demotivating to students. To avoid such problem, teachers are advised to "serve as a sounding board" to help writers clarify their intentions, to "see confusions in the text" and to "explore alternatives that they may not have considered" (Brannon \& Knoblauch, 1982, p. 162). In short, teachers should act as the co-interpreter of students' writing and the facilitator of the revision process.

\section{b. Overlooking students' varying levels} of writing ability

Another problem in teachers' written response is that they often treat all students alike when responding to their writing. In other words, their responses lack discriminating capacity to separate students from each other. In fact, previous research has proven that learners are different in terms of their ability, creativity, metacognition, etc. Each learner exhibits distinct characteristics that parallel their respective performance in their learning process. In writing, researchers found individuals' differences may lie in their 
respective approaches to revision. Therefore, Ferris et al (1995) recommended that writing teachers should respond somewhat differently to students of varying ability levels. However, the matter of how to do so remains unexplored in the relevant literature.

\section{Methodology}

\subsection{Subjects}

The subjects chosen for the study include 200 second-year students and 20 teachers who are currently teaching or have taught writing at the Faculty.

\subsection{Instrumentation}

In order to obtain adequate data for the study, four main instruments were used.

Instrument one: A questionnaire completed by the students

This questionnaire, which consists of 10 questions, was designed to elicit the information concerning the students' reactions or opinions about teachers' written feedback, factors affecting their comprehension of feedback, and their recommendations for improving it.

Instrument two: A questionnaire completed by the teachers

This questionnaire was intended to investigate the practices of giving feedback by the teachers in the Faculty who are teaching or have taught writing to second-year students before. It also consists of 10 questions, one of which is open-ended.

\section{Instrument three: Tape-recorded} interviews

A one-to-one interview was conducted after the administration of student questionnaire in each class. The questions in the interviews were basically based on those in the questionnaire, but were extended to include more open-ended questions to get more thorough understanding of the rationale behind each students' choice. Each conversation lasted for $15-20$ minutes.

Instrument four: The teachers' written commentary on the students' first and second drafts

The teachers' comments on the students' first and second drafts of the first three assignments were examined in order to obtain the most truthful information concerning the teachers' current practices of giving feedback in the English Division 2. Conclusions would then be made from the practices in terms of their strengths and weaknesses. This information will be triangulated to confirm and support the data collected from other sources, or it may reveal some other issues that the previous methods have not touched upon.

\subsection{Data collection}

On the first day of the survey, 20 sheets of questionnaire were delivered to the teachers in the Faculty. On the next two days, sets of student questionnaire were delivered to the second-year students. The required permissions needed to gain access to the students had been obtained in advance. Ten students were chosen by chance from the survey population to take part in a one-to-one interview.

After the interviews, the researcher asked for permissions from interviewees to collect their own drafts on which their teachers had commented so far. They were all willing to lend her some after the researcher ensured them that their names would not be identified in the data discussion. The copies of the first and second drafts contained handwritten commentary (marginal notes, betweensentence line notes, and endnotes) provided by the teachers. In all, I gathered 17 papers from the students (3-6 drafts per students). Of these, eleven first drafts and three revised drafts were usable for examination; the others were discarded because of the problem with photocopying. The reason why I could collect only five second drafts from the students was that some of the teachers in these classes did 
not require or ask their students to write a second version of the same paper.

\subsection{Data analysis}

This part of the study is the treatment of all the data collected from the survey questionnaires conducted on 20 teachers and 200 second-year students of English in the Faculty, the direct interviews with ten students and the analysis of the teachers' commentary on the students' sample drafts.

\subsubsection{Data analysis of teachers' survey questionnaire}

\subsubsection{Teachers' demographic information}

Among the 20 teachers taking part in the study, there were only three male teachers.
The teachers' ages ranged from 23 to 45 . Their experience in teaching English varied from less than a year to 23 years, during which they have spent from half a year to 10 years teaching writing to second-year students. Of these 20 teachers, about five had to take charge of two writing classes per semester. This means they had six periods of writing to teach per week and correspondingly, they had to mark as many as about 50 papers per week. This amount of marking was quite overwhelming to the researcher's belief.

\subsubsection{Analysis ofteachers'surveyquestionnaire}

a. Teachers' responding practices

What is the purpose of the teachers' feedback?

Table 1. Teachers' purposes of giving feedback

\begin{tabular}{lcc}
\hline \multicolumn{1}{c}{ Purposes } & Number of teachers & Percentage \\
\hline a. to help students improve their writing & 20 & 100 \\
\hline b. to justify for the grade & 7 & 35 \\
\hline c. to inform students that teachers are more knowledgeable than them & 0 & 0 \\
\hline d. to enhance the relationship between teachers and students & 10 & 50 \\
\hline
\end{tabular}

According to the information obtained from the survey, teachers might provide feedback to the students' writing for several important reasons, but the most important one was that they wanted to help their students improve the writing. This purpose has been realized by $100 \%$ of the teachers in the survey. Besides, nearly half of them used feedback as a base to justify for the grade they gave to their students. $50 \%$ of them utilized it as a means to enhance the relationship between them and the students. None of the respondents responded to the students' writing so as to demonstrate that teachers are in fact more knowledgeable than their learners.

How many times do the teachers respond to each of the students' assignments?

In terms of the number of times the teachers commented on each of the students' writing assignments, the majority of the subjects (14) employed one-shot commentary approach to respond to the students' writing, which means they responded and simultaneously evaluated the students' only one and also the final draft. Four other teachers seemed to be aware of the distinction between responding and evaluating, thus they commented on the first draft and then left the evaluation (in the form of grading) until the second, also the final draft. The two remaining teachers appeared to realize the benefit of the process of responding by commenting twice on the first and second draft, and leaving their evaluation to the final version when the student writing had been fully developed.

Which aspects in the students' writing do the teachers focus their feedback on?

The data showed that the teachers concentrated on different features of the writing. Eleven teachers in the survey concerned themselves with the construction 
of the paragraph, grammar, mechanics, vocabulary, and organization of ideas, but purposely not with content. They expressed the view that the students benefited most from comments about mechanics, grammar, and vocabulary. In addition, the comments of this nature did not take much time to write.

Three other teachers reported focusing on all six elements, with the emphasis on form - that is, the structure of the paragraph. They believed that form was of paramount importance to paragraph writing and that when marking the student writing, they could not help paying primary attention to this element.

The rest of the teachers (6) stated that they focused on the accuracy of grammar, vocabulary, and the organization of ideas. They felt that the students benefited most from comments on grammar. They occasionally gave comments about content and they deemed mechanics as trivial and not worth being commented on at all.

How often do the teachers use the following kinds of feedback to respond to the students' writing?

Table 2. Types and frequency of teacher feedback

\begin{tabular}{lccc}
\hline \multirow{2}{*}{ Feedback type } & \multicolumn{3}{c}{ Frequency(\%) } \\
\cline { 2 - 4 } & never & sometimes & frequently \\
\hline marginal & 10 & 45 & 45 \\
\hline end & 50 & 25 & 25 \\
\hline specific & 30 & 40 & 30 \\
\hline general & 20 & 20 & 60 \\
\hline positive & 45 & 30 & 25 \\
\hline negative & 0 & 25 & 75 \\
\hline
\end{tabular}

Table 2 reveals the sorts of feedback the teachers in FELTE never, sometimes, or frequently gave to their students. Each kind will be discussed in relation with the others.

In terms of the location of feedback, teachers in the Faculty tend to locate their comments in the margin of the students' papers. Surprisingly, about half of the surveyed population responded that they had never written any end comments in the student writing. This was probably due to the fact that these instructors did not have enough time to write long and summative comments, thus resorting to the formative ones as the main source of feedback.

To the question of whether the teachers in the survey provided general or specific feedback, the data showed that general comments were utilized more often by the majority of the teachers than the specific ones. This indicated that the responses the writers often received from their instructors were general, but not very specific. This comment type sometimes bewildered the recipients, thus confusing them, instead of helping them. Again, these teachers might not have enough time to write detailed commentary on every paper.

Also according to Table 2, the majority of the respondents tended to concentrate on the students' weaknesses, pointing out problems, rather than praising them for their strengths. These teachers probably thought that this was what their students actually needed and this was what they really expected their teacher feedback to be. Therefore, it was not surprising to discover that nearly half of the study population ( $45 \%)$ had never provided positive comments on the students' drafts.

How often do they use the following forms to provide feedback to the students' writing? 
Table 3. Forms and frequency of teachers' feedback

\begin{tabular}{llll}
\hline \multicolumn{1}{c}{ Forms of feedback } & \multicolumn{3}{c}{ Frequency (\%) } \\
\cline { 2 - 4 } & \multicolumn{1}{c}{ never } & sometimes & frequently \\
\hline a. question & 20 & 70 & 10 \\
\hline b. statement & 0 & 20 & 80 \\
\hline c. imperative & 0 & 15 & 85 \\
\hline d. exclamation & 25 & 65 & 10 \\
\hline e. marking the errors, but not actually correcting them & 15 & 10 & 75 \\
\hline
\end{tabular}

Among the forms used to provide feedback to the students' writing, imperative was utilized the most often by an overwhelming number of the respondents (17). This revealed that the comments the writers often received from their teachers were mostly orders with which they were supposed to comply. Statement was often used by as many as 16 teachers. Merely identifying the location of errors is also usually employed by 15 teachers. Exclamation and question are in relatively equal use with $10 \%$ of the teachers frequently, $65 \%$ sometimes, $25 \%$ never and $10 \%$ frequently, $70 \%$ sometimes, $20 \%$ never respectively.

b. Helping the students process feedback

Do the teachers often take the students' varying levels of writing ability into consideration when designing feedback?

$100 \%$ of the teacher subjects admitted that this idea had never occurred to their mind and even one of them put a question like "What have the students' different levels of writing ability got to do with the way they revise their papers?"

Do they explain their responding strategies to the students before applying them?

When asked in the next item on the questionnaire whether the teachers explain feedback strategies to the student writers before employing them, all of the subjects chose the option "No". Like the previous item, these teachers said that this idea never came to their mind.

Have the teachers ever asked their students to write a letter to tell them what they really thought about the feedback they received?
Likewise, when being asked whether they have ever intended to get feedback from their students concerning what the students really thought about the feedback they received, $100 \%$ of them admitted that they had never done as such. Consequently, these teachers have missed an opportunity to get to know what the students actually do when they revise, how they address the comments and why they disregard some of them; as for the writers, they would never have a chance to express their own feelings or opinions on the feedback they receive. Confusions, misunderstandings, or even ineffective revisions still pervade unless the instructors encourage thoughtful responses from their own students.

c. Teachers' problems in responding to the students' writing

With regards to the problems teachers encountered when giving feedback, most of them complained that written comments were time-consuming. Some of them thought that the students were not interested in their feedback. Some others disclosed that the students often made the same mistakes again. The respondents also specified some other difficulties such as sometimes the students' papers contained a lot of serious mistakes; as a result, they had to give a lot of comments and corrections throughout. Ultimately, they felt that the students' papers were not their own writing, but their teachers'.

What should the teachers do to improve their current feedback to help the students revise their papers more effectively? 
At the end of the questionnaire, no recommendations were given. Possibly, these teachers had no idea of how to improve their current feedback or they might not have been aware of the great importance of effective and genuine feedback on the students' revision.

4.3.2. Data analysis of students' survey questionnaire and direct interviews

\subsubsection{Students'demographic information}

Table 4. Respondents by age and gender

\begin{tabular}{|c|c|c|c|}
\hline \multirow{2}{*}{ Age } & \multicolumn{2}{|c|}{ Number of students } & \multirow{2}{*}{ Total } \\
\hline & Male & Female & \\
\hline 19 & 3 & 26 & 29 \\
\hline 20 & 11 & 72 & 83 \\
\hline 21 & 10 & 72 & 82 \\
\hline 22 & 0 & 5 & 5 \\
\hline 23 & 0 & 1 & 1 \\
\hline Total & 24 & 176 & 200 \\
\hline
\end{tabular}

The total number of the students chosen in the study was 200 of which 24 were male and 176 were female. Most of them were aged between 20 and 21 (165 students, accounting for $82.5 \%$ of the subjects). 21 students were 19 years old. The rest of the students belonged to the age groups of 22 and 23.

Table 5. Respondents' learning experience and place of domicile

\begin{tabular}{ccccccc}
\hline & \multicolumn{3}{c}{ Students' learning experience } & \multicolumn{3}{c}{ Place of domicile } \\
\cline { 2 - 7 } & $\mathbf{5 - 7}$ & $\mathbf{8 - 1 0}$ & $\mathbf{1 1 - 1 3}$ & Countryside & Town & City \\
\hline Number of students & 112 & 67 & 21 & 92 & 80 & 28 \\
\hline Percentage & 56 & 33.5 & 10.5 & 46 & 40 & 14 \\
\hline
\end{tabular}

The majority of the study subjects came from the countryside (92 students) and from towns (80 students) while 28 were from big cities like Hanoi, Hai Phong, or Nam Dinh. Their different places of domicile reflect their different learning backgrounds.

The number of years they had been learning English ranged from 5 to 13 years. More than half of them (112 students) had spent from 5 to 7 years studying English, and 67 of them had learning the language for 8 to 10 years. Only 21 students had experience of 11-13 years in learning English. None of the students had studied English abroad.

The students have been studying writing for at least a year at the University. Their average mark in the first-year final writing test varied from 5 to 9 out of 10 . About $43 \%$ of them had got marks from 5 to 6 , and $52 \%$ from 7 to 8 . Approximately $5 \%$ of the whole survey population got mark 9 in their final test. These different test results reflect the varying ability levels of writing possessed by the second-year student writers in the Faculty.

In short, the subjects in the study came from different parts of the country, had different experience of learning the language, and thus were of varying levels of writing ability, which is believed to affect their respective performance in their revision.

4.3.2.2. Analysis of students' survey questionnaire and direct interviews

a. Students' opinions on the feedback they received

What do the students think about the importance of teachers' feedback to their writing?

The student respondents valued the importance of their teachers' feedback in different ways. $20 \%$ of them thought that 
teachers' feedback was important, $57 \%$ viewed it as very important, and about $16 \%$ extremely important. The importance of feedback lay in the fact that the writers needed to be told why they got such a grade and they also wanted to know what they could improve on what they had done badly. However, some students (14) still expressed their unfavorable view towards feedback, saying that it was not important at all.

How many times do the students want their teachers to respond to each of their writing assignments?

In terms of the number of times the students would like their teachers to respond to each of their assignments, about $94 \%$ expressed their preference for two or three times. Obviously, most of the writers expected more intervention from their teachers with a view to further perfecting their papers.

However, about $6 \%$ of the subjects (12 students) were contented with just one-time commenting. Perhaps, these students were not very keen on revising their drafts several times or they did not have motivation in rewriting their papers.
Which aspects in the writing would the students prefer their teachers' feedback to focus on?

When asked in another item on the questionnaire what their preferences for feedback were, 91 out of 200 students said that they preferred more feedback about content, 54 preferred more on organization, 38 on grammar and mechanics, and 17 on vocabulary use. None of them expected a focus on form - the structure of the paragraph since this element was not their problem. The eight students in the interview reported that their teachers usually gave much attention to mechanics, grammar, and vocabulary on their drafts, some attention to organization, and little to content. One of them said, "I would have liked it if the teacher had commented on the ideas of my writing and whether she liked them or not". This might explain why most of the students would expect their teachers to act in another direction.

Which kind of feedback would the students prefer to receive from the teachers?

Table 6. Students' preferences for teacher feedback type

\begin{tabular}{llll}
\hline \multirow{2}{*}{ Options } & \multicolumn{3}{c}{ Questions } \\
\cline { 2 - 4 } & 4 & 5 & 6 \\
\hline $\mathrm{a}$ & 4 & 4 & 97.5 \\
\hline $\mathrm{b}$ & 4.5 & 18 & 0 \\
\hline $\mathrm{c}$ & 91.5 & 78 & 2.5 \\
\hline
\end{tabular}

Table 6 reveals the students' preferences for each kind of teachers' feedback. As apparent from the table, most of the respondents $(91.5 \%)$ were in favor of the simultaneous appearance of praise and criticism on their papers. They elaborated that praises should come first, and then some criticism follows to help them improve their writing. Few students like to receive positive comments, and even fewer prefer critical responses alone.

As for the location of teachers' feedback, $78 \%$ of the students in the survey said they would benefit from the combination of both (marginal notes and endnotes). The former had the advantage of being immediate and specific while the latter was an overview of their writing problems. Still, if they had to opt for one, $18 \%$ of the students would like their teachers to write end commentary while the rest $(4 \%)$ would prefer marginal responses.

Also according to Table 6, none of the students in the study appreciated general feedback. Below is what they said.

"Teachers' feedback is too general for us to understand." 
"General feedback doesn't provide much information for me to revise the paper."

"Sometimes I don't understand what the teacher means or wants me to do in their comments."

This situation implies that the students

Table 7. The helpfulness of teachers' feedback forms to the students' revision

\begin{tabular}{lccc}
\hline \multicolumn{1}{c}{ Forms of feedback } & not helpful at all & helpful & very helpful \\
\hline a. question & $4(2 \%)$ & $108(44 \%)$ & $88(54 \%)$ \\
\hline b. statement & $25(12.5 \%)$ & $115(57.5 \%)$ & $60(30 \%)$ \\
\hline c. imperative & $32(16 \%)$ & $144(72 \%)$ & $24(12 \%)$ \\
\hline d. exclamation & $60(30 \%)$ & $104(52 \%)$ & $36(18 \%)$ \\
\hline e. marking the errors, but not actually correcting them & $93(56.5 \%)$ & $79(29.5 \%)$ & $28(14 \%)$ \\
\hline
\end{tabular}

In general, the majority of the students highly valued feedback in the following forms: question, statement, imperative, and exclamation, among which question was the most helpful one. In contrast, marking the problematic areas but not actually correcting them was assessed by $56.5 \%$ of the students as not very helpful at all. This could be due to the fact that this feedback form provided no suggestions or instructions as to what the writers should do to correct their mistakes.

b. Factors affecting students' comprehension of teachers'feedback

Do the students find it easy to understand their teachers' feedback? If not, what are the factors? What strategies do they use to overcome this problem? strongly demand feedback that is clear and specific.

How helpful is the Teachers' feedback in the following forms to the students' revision? 
said that they did not know whether it was necessary to follow the suggestions. Clearly, these students would prefer their teachers to be more specific and direct in their commentary.

Meanwhile, as many as 76 students complained about the teachers' responding strategies, saying that it could be an obstacle to their comprehension of feedback. They specified that teachers normally did not correct all of their errors, but only some of them, or they just corrected only minor problems on the surface of the writing without commenting on any major problems in the content, or worsely the teachers just underlined or circled the mistake, but gave no explanations or suggestions to help them to correct it. One of the students in one interview stated, "If the teachers just mark the errors, but don't correct them, this is rather difficult to understand my mistakes".

What strategies did the students use to resolve the problem?

Table 9. Students' strategies

\begin{tabular}{lcc}
\hline \multicolumn{1}{c}{ Students' strategies } & Number of students & Percentage \\
\hline a. ask teacher or peer for help & 27 & 32 \\
\hline b. consult a grammar book or dictionary & 18 & 21 \\
\hline c. consult previous writings & 10 & 12 \\
\hline d. study harder & 6 & 7 \\
\hline e. doing nothing & 23 & 28 \\
\hline
\end{tabular}

When asked what strategies they used to overcome the above problems, some of the students responded that they would ask the teachers or peers for help and consult a grammar book or dictionary. Some others suggested, "study harder" or "consulting the model or previous writing". The remaining students said they would do nothing; they just left the problems there unresolved.

c. Students' recommendations for improving the current teachers'feedback

For the question of what the teachers should do to help the students revise their writing more effectively, numerous recommendations were given concentrating on the following matters:

First of all, many students would like their teachers to encourage or require them to write at least two drafts for one assignment to provide them with a chance to further perfect their ideas and make their writing as good as it can be. It was understandable that as the students were engaged in multipledraft writing, they needed feedback from the teachers to these various drafts. Thus responding should be perceived as a process, rather than a single act in this situation.
Secondly, the majority of the students felt that their writing problems were not adequately dealt with; as a result, they would like their teachers to write more comments as well as make all corrections of their errors on their writing, even the minor ones. Especially, a relatively high percentage of the students (30) wanted their teachers to comment more on the content of the writing and the organization of their ideas.

In addition, many of the respondents requested that teachers' feedback should be clearer and more specific. They particularly demanded the teachers to provide suggestions or corrections besides their marking or identification of problematic areas because this would help them to revise more easily. Besides demanding the teachers to provide more critical commentary to improve the writing, the students in the survey did not forget to remind the teachers that they should also include some positive comments in the feedback to give them some motivation to make better attempts in the next writing.

Finally, it was interesting to find out that several of the students (17) would like their teachers to call their names at the beginning of the end commentary. This would help to 
give them the feeling that they had been given personal attention and what is more, they felt that the teachers were talking to them. This desire was legitimate and should not be dismissed.

In short, the analysis of the questionnaires to the teachers and students in the Faculty has provided primary important information concerning what the teachers actually do as they respond and what the students really think of these written responses as well as what they would like their teachers to do to help them revise their papers more successfully. In the following section the author will look at the sample of the teachers' comments on the students' first and second drafts in order to obtain more truthful information of what the instructors have actually done in response to the students' writing.

\subsubsection{Observation of the teachers'commentary} on the students'first and second drafts

The students' first and second drafts from the first three assignments, which focused on such paragraph types as writing instructions (time-order paragraphs), describing (spaceorder paragraphs), and stating reasons using examples, were examined. The topics chosen for writing were among those given at the end of each unit in the coursebook "Writing Semester 3". If the students were not interested in any of them, they were allowed to choose one of their own interests. This explained why the topics selected for each writing paper varied from individual to individual.

Through observing the teachers' written comments on the collected drafts, the researcher came up with the good points and bad points of each teacher's responding practice, which further reinforced the reliability and truthfulness of the previous data analysis. This observational information will be incorporated in the following presentation of the findings.

\section{Findings}

This section presents the answers to the research questions proposed at the beginning of the study.

\section{Research question 1: How do the teachers respond to the student writing?}

(i) What is the purpose of teachers' feedback?

The teachers' main purpose of giving feedback to the students' writing was that it helped the students improve the quality of their papers in terms of both content and form. This purpose is relevant to the most important function of teachers' feedback as a pedagogical tool for writing improvement. Besides, many teachers also used feedback as a means either to justify for their grades or to enhance the rapport between them and their students.

(ii) Do they provide single-draft or multiple-draft feedback?

The findings indicated that most of the second-year writing teachers $(87 \%)$ stuck to the single-draft writing, thus one-shot commenting. One possible result of this practice was that responding was mixed with evaluating, often in the form of a grade. This led to another serious consequence - that is, it encouraged the students to believe that their first drafts were finished drafts and they did not need to further develop their ideas, to communicate their intention adequately, to make further invention in their subsequent writing.

Still, a small number of the teachers seemed to be aware of the importance of multiple-draft writing by encouraging their students to produce at least two versions of the same paper. This enabled the writers to revise their drafts just one or two times before submitting the final version for evaluation. In addition, the observation of the students' drafts indicated that the students sometimes made improvements in the second drafts not as a result of the teachers' feedback. This would suggest that rewriting alone is a worthwhile activity and should be encouraged. 
(iii) What aspect(s) of the students 'writing do they focus their feedback on?

Feedback on grammatical, lexical, mechanical errors was more frequently seen on the students' drafts than the other, namely, on content and organization. This result suggests that the teachers paid more attention to the form than the content, which might result in the students' submission of papers almost flawless in grammar but lacking in substance.

(iv) What types of feedback do they often give to the student?

It was quite dismal to discover that some less effective feedback types to the students' revision were provided more often than the more effective ones.

Firstly, the results indicated that the teachers seldom combined negative with positive comments. The majority of them only paid attention to the students' mistakes, which might make the students think of them as error hunters, but not helpful readers whose comments would encourage them to write more and better paragraphs in the next attempt. Although some positive comments were made, they were too general because they did not refer to any specific points in the students' texts. Some others, however, have realized the positive effect of combining the two types positive and negative, but they were of a small number.

For the second pair of comments: marginal versus end responses, the findings were also discouraging. Teachers usually wrote marginal and between-sentence comments, which only helped the writers change some discrete items in their writing, but the students would then fail to obtain an overview of their writing strengths as well as their own writing problems.

The result was especially dismal with regard to the final feedback type: general versus specific. Far more general responses, which only served to confuse the students, were provided to the students than the specific ones. We were students once and we knew how important the teachers' feedback was. Can we blame our students today if they become lazy or indifferent to their writing revision?

(v) What forms of feedback do they often use to respond to the students' writing?

In this study, feedback in imperative form appeared to be used the most often. Less frequent were statements or marking the errors, but not actually correcting them, whereas questions that encourage the students' thinking process or ask for further information and exclamations were sometimes applied. The findings indicated that the second-year writing teachers were in favor of making requests for revision and identifying or marking the problems, but giving no suggestions to solve them. On the one hand, the practice helped the writers see the urgency to implement the advice; on the other hand, it was in danger of appropriating the students' ideas. What is more, merely marking the errors, but making no corrections could frustrate the apprentice students because they did not know how to correct the mistakes, especially the difficult ones.

\section{Research question 2: What have the teachers done to help the students process their comments successfully?}

(i) Do they take the students' varying levels of writing ability into consideration when designing feedback?

Although researchers have proven that students' different levels of writing ability could affect their performance in their writing revision, $100 \%$ of the teachers in the survey had never taken this matter into account. In other words, they responded to the students' writing without considering how low-ability or high-ability writers handled their feedback. Thus it is quite plausible to conclude that teachers' feedback sometimes may not be relevant to the students' levels of proficiency.

(ii) Do they explain their responding strategies to the students before using them? 
The research revealed that none of the teachers intended to do as such simply because this idea had never occurred to their mind. This explained why the students reported confusions over their teachers' responding strategies.

(iii) Have they ever asked or required their students to write a letter to tell them what they actually thought about the feedback they received?

The study results indicated that all of the teachers in the survey were new to the idea of getting feedback from their students as to the effects of their feedback on the students' revision. This issue would be taken into consideration when recommendations for improving the effectiveness of teachers' feedback are presented.

\section{Research question 3: What problems do they encounter in responding to the students' writing?}

The majority of the teachers complained that written feedback was time-consuming. In spite of the fact, they insisted that they should continue to write comments on the students' papers because comments help the writers improve; because written comments seem more feasible and more thorough than oral responses on every paper; and because for most writing teachers, the job requires them not only to evaluate their students' writing but to be able to justify their evaluation.

Another problem to note is that the students sometimes made the same mistakes again. One possible cause of the situation is the annotations the teachers made on the students' papers have not been internalized into the students' minds. Although they have made the alternation correctly, they had no idea what the principle behind the teacher's directive might have been and therefore were unable to correct the same type of error in another piece of writing.

The final problem that the teachers in the study might encounter in giving feedback to the students was that the students' papers were sometimes full of mistakes; as a result, they could not help catching every error the students made, scribbling over the paper with red marks and corrections. Despite the effort, the errors persist.

\section{Research question 4: What are the students' opinions on the feedback they received?}

(i) What do they think about the importance of teachers'feedback to their writing?

The study revealed that most of the students viewed teachers' feedback as important to their writing since it provided useful information to help them rewrite their papers, produce the better version in the next attempt. However, some of the students possessed negative attitudes towards feedback, considering it not important at all. This result suggests two conflicting but coexisting truths that the students pay a great deal of attention to teachers' feedback, which they believe to help them to make effective revisions, and that some others ignore or avoid the suggestions given in teachers' commentary.

(ii) What are their attitudes towards the feedback they received?

- Would they like their teachers to respond to their writing as a process?

It was encouraging to discover that most of the student writers were in favor of process responding rather than one-shot commenting. In other words, these students expected greater intervention from their teachers who, in the process of responding to their writing, would offer them suggestions, options, or other ways of looking at what they have said; on this basis they would make necessary changes to further perfect their papers.

- Which aspect(s) in the writing do they want their teachers' feedback to focus on?

The research results showed that most of the students indicated a preference for more teacher comments on content and 
organization, and nearly one-third wanted more comments on grammar, mechanics, and vocabulary. None of them said that teachers should focus on the overall structure of a paragraph because they were well informed about this aspect.

- What are their attitudes towards the types of feedback they received?

The results of the study stressed that a single comment type (e. g., positive comment alone - absent of any criticism or identification of errors) was not sufficiently motivating to the majority of these university-level EFL learners to produce improvement; although it should be admitted that certain type could lead to improvement, it was not as effective as when it was combined with another kind, for instance, marginal plus end notes. However, there was one exception with regard to the final pairs of feedback - general versus specific - because most of the students in the survey expressed their strong preferences for clear and specific responses, which provided them adequate information to revise their papers.

- What forms of feedback help them revise the best?

The research results suggested that question was the most effective form in encouraging the writers to revise and edit their own papers. Meanwhile, merely marking the problematic areas, but not actually correcting them was proved to be the least helpful due to the fact that the writers were less clear about what they should do to correct their errors.

(iii) What are the factors affecting the students' comprehension of teachers' feedback? What strategies do they use to resolve these problems?

As many as 84 students in the survey responded that it was not easy to understand their teachers' feedback. The main reason was the overgenerality of the feedback. Even though they had tried to decipher a comment, they had no idea how to handle it. Another cause of the problem lay in the language of the commentary. New words or structures were sometimes reported to prevent the writers from comprehending the response fully. Hedges were also claimed as another factor. Last but not least, the responding strategy itself was also a hindrance in that the students might not understand why their teachers just corrected few mistakes and left others go uncorrected or why teachers merely marked the error, but did not correct it for them.

These confusions continually piled up in their mind, making the act of writing somewhat complex and tiring. Some of the writers managed to have their confusions clarified by consulting a dictionary, grammar book, the model text, or even previous writing pieces. Some others would ask the teacher directly or ask their peers for help. Yet a relatively large number of the students (23) would choose to leave their writings there unresolved.

\section{Research question 5: What do the students want their teachers to do to help them revise more successfully?}

A great number of suggestions for improving feedback have been proposed focusing on the following matters. First of all, the students would like their teachers to encourage them to rewrite their drafts and respond to these writings until they become as good as they can be. Secondly, they expected more teachers' comments on each of their papers, especially those on content and organization of their writing. At the same time, they demanded teachers' feedback should be clearer and more specific in order to help them revise their drafts effectively. What is more, teachers should keep a balance between positive and negative comments to motivate them to revise and simultaneously help them to make improvement. Finally, the students would like the teachers to address their name at the beginning of an end comment because this would give them the feeling that they had been personally treated by the teachers. 


\section{Recommendations}

Following are some suggestions to the teachers in the English Division 2, Faculty of English Language Teacher Education, University of Languages and International Studies, Vietnam National University, Hanoi.

(1) Helping the students process feedback successfully

As already noted, the students may either respond to the teacher commentary or ignore it altogether. This awareness should both encourage the teachers in their work and alert them that some students whether because of laziness or misunderstanding of teachers' feedback may not utilize their feedback for revision. Teachers should, therefore, be careful (a) in their own responding strategies, (b) in explaining those strategies to their learners, (c) in selecting the appropriate language to use in each commentary, and (d) in including hedges in their comments.

Besides, the teachers should also get feedback from the students concerning what the students actually think about their feedback. One technique for encouraging such a thoughtful response is to require a revise-and-resubmit letter, analogous to what writers produce when they submit a revised manuscript to a journal after receiving reviews. In this letter, the students systematically review the feedback they have received, explaining how they have addressed the reader's comments and why they may have disregarded some of them. This technique encourages reflection upon both feedback and revision yet allows the writers some freedom to ignore or disagree with comments they have received as long as they can justify their decisions.

\section{(2) Making comments more effective \\ * The need for more emphasis on content and organization}

The study has uncovered an apparent mismatch between the choice on the teachers' part not to deal with content and a clear desire on the students' part to have such feedback. Therefore, EFL composition teachers should pay more attention to this aspect of the students' writing. It is not the intention of the author to be prescriptive. However, we feel that this feedback could be greatly beneficial to the EFL writers who always have to struggle to have their intentions communicated successfully to the readers.

Although there remain some other students (maybe low-ability ones) whose expressed emphasis was on grammar, mechanics, or vocabulary; as teachers, we need to bear in mind that learners' expectations and preferences may derive from their previous instructional experiences, experiences that may not necessarily be beneficial for the development of writing. Hence, in this case it may be vital for the teachers not to cater to the students' expectations but to shift those expectations according to what contributes most to the development of writing skills. Grammar does need attention, but we need to give first priority to content and organization. Given this perception, teachers can respond in one of the two following ways:

(i) They can follow the advice of Raimes (1992), Ferris and Hedgcock (1998), and others by responding only to the student writers' ideas and organization on early drafts provided that they carefully explain their strategies and accompanying justifications to the students.

(ii) They can blend content and grammar responses on all drafts, but vary the emphases of the responses. For instance, on first drafts, they can respond primarily to content but make a general end comment about the writer's grammar problems. On later drafts, when the students' ideas are more solidified, the teacher can provide specific word- and sentence-level feedback while still making general comments on the students' ideas. 


\section{* The need for text-specific feedback}

Teachers' comments on the students' papers are more helpful if they are textspecific. However, it was harder than it had first appeared to classify comments as either text-specific or general. For instance, if the comment "Good example" is written in the margin next to the example being praised, it is most likely clear to the writer which specific point is being commented on. Another example is "You have a lot of verb tense errors in this draft. I've underlined some for you." It could be argued that this comment is text-specific because it refers to a particular problem of the text at hand. Perhaps the key criterion needs to be whether the comment is clear and helpful to the student to commit changes in their subsequent drafts, rather than it has to conform to general notion of what is text-specific.

In addition, when summary comments in which the teachers communicate general rules that will be carried across drafts and throughout the writing class are considered, the above criterion proves to be relevant. After all, teacher feedback on the students' papers is an important form of communication and instruction, not merely a fix-it manual for a particular draft. If every comment on a paper is text-specific, it is impossible for the novice writers to internalize the concepts being instructed and thus being unable to transfer these instructions to their subsequent writings beyond the immediate drafts. Therefore, teachers should write on the students' papers an end note that provides a balance of textspecific and summary comments to help the writers be aware of their specific as well as major problems not only in the progressing work but also in the future assignments.

An example to demonstrate the practice is as follows:
Cuong,

You have a well-organized paragraph with very good topic and concluding sentences. However, you need to supply more examples and evidence to support your arguments.

Also, you have some major grammar mistakes. Sentence fragments (incomplete sentences) are the most serious.

* Location of feedback

Teachers' written responses to students' papers can take the form of marginal or terminal notes. In this study, it was found that most of the teachers gave only marginal comments; some provided summary comments. We strongly recommend that teachers should judiciously combine both of the types because of their respective advantages. Marginal comments have the advantage of immediacy (the teacher's response can be given at the exact point in the essay where the problem occurs) whereas an endnote gives the writers an overview of their own strengths and weaknesses.

Based on our own experience and adapted from Ferris and Hedgcock's suggestions, we suggest the following procedures for teachers to use for combining marginal and terminal comments effectively in responding to the students' papers:

(i) Read the entire paper through at least once without writing anything on the paper;

(ii) Read the paper through again, paying attention to the most important issues of content and organization that you might address;

(iii) Compose your endnote, which should be comprehensive, but selective. Address the points you want to make clearly, but do not overwhelm the student by attempting to address every single problem in the paper. Focus on the most important issues;

(iv) Go back and add marginal comments that highlight specific examples of the general points you made in the endnote.

In this way, it is hoped that the teachers' attempt at comment on the students' writing does 
not end up as a rewrite of the students' paper.

* Balancing positive and negative responses

Much has been written about the importance of placing comments of praise side by side with constructive criticism. However, as the research results indicated, the teachers were mostly negative in their commentary while the students did expect some encouraging remarks from them. The problem with these "monster responses" is that they terminate the dialogue and the growth of the piece of writing. There is not much the writer can do with or learn from such comments.

This situation leads to a very important suggestion that the teachers should pay attention to both strengths and weaknesses of the students' papers. The comments of the former nature will greatly motivate the writers to revise while those of the latter will constructively show them where they have gone wrong and what action they should take in order to improve their papers.

\section{* Providing additional guidance}

It appears from the study that teachers' employment of marking system without providing any further information caused difficulty to most of the writers in their revising process. All too often, the students would not commit to change or the changes they made tend to be negative or effect-mixed. Therefore, besides indicating the existence of a problem, the teachers should also provide guidance to their students, especially the low-ability ones, either by adding an explicit suggestion as to how the students should do to correct it or by explaining briefly what is wrong with the underlined area so that the students can be aware of the problem and take appropriate measure to eradicate it.

In addition, the teachers are encouraged to utilize feedback in question form wherever possible both to stimulate the students' thinking processes and to avoid appropriating the students' texts. Yet they need to be aware of the fact that questions may sometimes confuse students, thus providing additional guidance is really helpful in helping students to be clearer about how to implement the change successfully.

\section{* Writing personalized comments}

When responding to the students' texts, it is helpful to think of teachers' feedback as the continuation of a dialogue between reader and writer. This means that teachers should address the students by name at the beginning of an endnote, or even they may sign their own names, as at the end of a personal letter. It can also be appropriate to respond personally to the points in the text (e.g., "I like this idea", or "I'm confused by your argument here"). In this way, student writers will feel that they have been given a personal treatment, and that their teachers are really helpful; thus they certainly adopt a positive attitude towards these teachers, which contributes greatly to the development of relationship between the students and their instructors.

In conclusion, the author has recommended some suggestions that are hoped to change the current practices, making the teachers' commentary essentially one of the most valuable pedagogical tools for the students' writing improvement. Although the suggestions mainly target at the teachers at FELTE, ULIS - VNU, teachers at other language education institutions can also utilize the ideas in their own context if relevant.

\section{References}

Brannon, L., \& Knoblauch, C. H. (1982). On students' rights to their own texts: A model of teacher response. College Composition and Communication, 33, 157 166.

Byrne, D. (1991). Teaching writing skills - Longman handbooks for language teachers. Longman: London.

Chaudron, C. (1984). The effects of feedback on students' composition revisions. RELC Journal, 15(2), 1-14. 
Cohen, A. D. \& Cavalcanti, M. C. (1990). Feedback on compositions: Teacher and student verbal reports. In B. Kroll (Ed.), Second language writing: Research insights for the classroom (155-177). Cambridge University Press: New York.

Dheram, P. K. (1995). Feedback as a two-bullock cart: A case study of teaching writing. ELT Journal, 49(2), 160-168.

Escholz, P. A. (1980). The process models approach: Using products in the process. College Composition and Communication, 31, 20-37.

Faigley, L., \& Witte, S. (1981). Analyzing revision. College Composition and Communication, 32, 400-414.

Fathman, A., \& Whalley, E. (1990). Teacher responding to student writing: Focus on form versus content. In B. Kroll (Ed.), Second language writing: Research insights for the classroom (178-190). Cambridge University Press: New York.

Ferris, D. (1995). Can advanced ESL students become effective self-editor? The CATESOL Journal, 8(1), 41-61.

Ferris, D. R. (1997). The influence of teacher commentary on student revision. TESOL Quarterly, 31(2), 315 - 339.

Ferris, D. R., \& Hedgcock, J. (1998). Teaching ESL composition: purpose, process, and practice. Lawrence Erlbaum Associates: Mahwah, New Jersey.

Ferris, D., Pezone, S., Tade, C. R., \& Tintin, S. (1995). Teacher commentary on student writing: Descriptions \& Implications. Journal of Second Language Writing, 6(2), 155-182.

Gee, T. C. (1972). Students' responses to teacher comments. Research in the Teaching of English, 6, 212-219.

Griffin, C. W. (1982). Theory of responding to student writing: The state of the art. College Composition and Communication, 33, 296-310.

Hedgcock, J., \& Lefkowitz, N. (1994). Feedback on feedback. Journal of Second Language Writing, 3, 141-163.

Hedge, T. (1990). Writing: Resource books for teachers. Oxford University Press.

Hillocks, G. (1986). Research on written composition - New directions for teaching. Urbana, III.: ERIC Clearinghouse on Reaching and Communication Skills and the National Conference on Research in English.

Ho, M. K. (2001). Research on the second writing process. New York: Cambridge University Press.

Keh, C. L. (1989). Feedback at the product stage of writing: comments and corrections. Guidelines, 11(2), 18-24.

Krashen, S. D (1984). Writing, Research, Theory, and Applications. Oxford: Pergammon Institute of English.

Leki, I. (1990). Coaching from the margins: Issues in oral and written responses. In B. Kroll (Ed.), Second language writing: Research insights for the classroom (57 - 68). Cambridge University Press: New York.
Murray, D. (1978). A writer teaches writing: A practical method of teaching compositions. Boston: Houghton Mifflin.

Oshima, A., \& Hogue, A. (1991). Writing Academic English. Addison - Wesley Publishing Company.

Penaflorida, A. H. (2002). Nontraditional forms of assessment and response to student writing: A step toward learner autonomy. In Richards, J. C., \& Renandya, W. A (Eds.), Methodology in Language Teaching - An Anthology of Current Practice. New York: Cambridge University Press.

Perl, S. (1979). The composing process of unskilled college writers. Research in the Teaching of English, 13, 317-336

Porte, G. K. (1999). The Etiology of poor second language writing: The influence of perceived teacher preferences on second language revision strategies. In Lee I. \& Ferris D. (Eds.), Journal of Second Language Writing, 6(1), 61-78.

Raimes, A. (1992). Anguish as a second language? Remedies for composition teachers. In A. Freedman, I. Pringle, and J. Yalden (Eds.), Learning to write: First language \& second language (258-272). London: Longman.

Reid, J. M. (1993). Teaching ESL writing. Prentice Hall Regents: Englewood Cliffs, New Jersey.

Seow, A. (2002). The writing process and process writing. In Richards, J. C., \& Renandya, W. A (Eds.), Methodology in Language Teaching - An Anthology of Current Practice. New York: Cambridge University Press.

Silva, T. (1990). Second language composition instruction: development, issues, and directions in ESL. In B. Kroll (Ed.), Second language writing: Research insights for the classroom (11-23). New York: Cambridge University Press.

Sommers, N. (1980). Revision strategies of student writers and experienced adult writers. College Composition and Communication, 31, 378-388.

Sommers, N. (1982). Responding to student writing. College Composition and Communication, 33, 148156.

Taylor, B. (1981). Content and written form: A two-way street. TESOL Quarterly, 16, 5-13.

White, R. V. (1990). Academic writing process and product. In Robinson, P. C. (Ed.), Process and Product, ELT Documents, 129, 4-16. Modern English publications in association with the British Council.

Zamel, N. (1983). The composing processes of advanced ESL students: Six case studies. TESOL Quarterly, 17, 165-187.

Zamel, V. (1985). Responding to student writing. TESOL Quarterly, 19, 79-202. 


\title{
PHẢN HỒI VIẾT CỦA GIÁO VIÊN: LÀM THẾ NÀO ĐỂ PHẢN HỒI BÀI VIẾT CỦA SINH VIÊN HIỆU QUẢ HƠN?
}

\author{
Phùng Thị Kim Dung \\ Trường Đại học Ngoại ngũu, Đại học Quốc gia Hà Nội \\ Phạm Văn Đồng, Cầu Giáy, Hà Nội, Việt Nam
}

Tóm tắt: Phản hồi của giáo viên đối với bài viết của sinh viên vẫn luôn là vấn đề quan trọng nhưng luôn bị sao nhãng trong những nghiên cứu về dạy viết ngôn ngữ thứ 2 . Nghiên cứu này nhằm bổ sung vào tổng quan lý luận thông qua việc phát triển và thực hiện một nghiên cứu điều tra cách thức giáo viên phản hồi bài viết của người học trong thực tiễn và ý kiến của người học đối với phản hồi của giáo viên cũng như những khuyến nghị nhằm cải thiện phản hồi viết của giáo viên. Nghiên cứu có sự tham gia của 200 sinh viên năm thứ 2 và 20 giáo viên dạy viết tại Khoa Sư phạm tiếng Anh, Trường Đại học Ngoại ngữ - Đại học Quốc gia Hà Nội. Giáo viên và sinh viên được mời trả lời bảng câu hỏi, tham gia phỏng vấn và cung cấp bài viết đã được giáo viên nhận xét để phân tích. Kết quả nghiên cứu cho thấy một số điểm hạn chế trong cách thức, trọng tâm, loại và hình thức phản hồi của giáo viên cũng như những gì giáo viên đã làm nhằm giúp người học xử lý phản hồi hiệu quả. Đồng thời nghiên cứu cũng cho thấy có sự không tương thích giữa những gì sinh viên mong đợi và những gì giáo viên cung cấp trong phản hồi. Dựa trên cơ sở này, nghiên cứu đã đề xuất một số gợi ý nhằm giúp giáo viên cải thiện hoạt động của mình, giúp người học sử dụng phản hồi hiệu quả hơn, nhằm tạo môi trường mà ở đó người học có thể học viết một cách dễ dàng và thành công hơn.

Tù khóa: Phản hồi, đường hướng dạy viết theo quá trình và dạy viết theo sản phẩm, nội dung, hình thức, chỉnh sửa bài viết 